\title{
Development of Learning Technology in the Course Marketing Management 1
}

\author{
Verinita $^{1, *}$, Yanti $^{2}$, Ratni Prima Lita ${ }^{3}$ \\ 1Management Study Program, Faculty \& Economics, Universitas Andalas, Padang, Indonesia \\ 2Management Study Program, Faculty \& Economics, Universitas Andalas, Padang, Indonesia \\ 3Magement Study Program, Faculty \& Economics, Universitas Andalas, Padang, Indonesia \\ *Corresponding author. Email: verinitaarsya@eb.unand.ac.id
}

\begin{abstract}
Teaching of Marketing Management 1 courses has been using the method of exposure to marketing management concepts and theories. The lecturer explains the concept or theory in class. The next week the lecturer gave the case and the students discussed the case. The case is determined by the lecturer. So that it causes students to feel bored because there is no media and video that interest them to study this course material. As a result, students only understand the concept so that the styling of the concept of Marketing Management 1 is not optimal. This is due to the low variation in the teaching methods and teaching media used. Because it is necessary to provide a learning method using the blended learning method. Andalas University already has an adequate Learning Management System (LMS) platform for elearning, but not many have used it.Blended learning is a learning method that combines face-to-face meetings with online material in harmony. This blended learning will create a learning experience for learning outcomes that have been set in the Marketing Management course 1. In blended learning, the Marketing Management 1 course implements the elearning process 4 out of 16 meetings in 1 semester. The lecturer has a semester learning plan in the form of blended learning which includes synchronous and asynchronous learning activities. Learning content is uploaded at Ilearn Andalas University in the form of instructional videos. Implementation of learning with this learning method creates student curiosity to find out what videos and other materials the lecturer will provide at the next online learning meeting. Students feel more excited, their creativity will increase to explore abilities in technology. This online learning method increases student understanding of the Marketing Management material for the better because the material provided is more interesting
\end{abstract}

Keywords: Development of learning technology, blended learning, videos, creativity

\section{INTRODUCTION}

Marketing Management Course 1 is a compulsory subject for the 3rd-semester students in the Management study program, Faculty of Economics, Andalas University. Students can take Marketing Management 1 if they have passed Introduction to Business, Introduction to Management, and Introduction to Accounting.

Marketing Management 1 is a course designed to widen students' insight into the concept of marketing management applied in organizations and societies. This course discusses the function of marketing organizations as a process in creating, communicating, and conveying values to customers and building relationships with customers that will benefit the organization and stakeholders.

After taking this course, students are expected to obtain learning outcomes, namely understanding basic marketing concepts and being able to apply the concept of marketing in a company. The learning objective of this course is to enable students to comprehend and analyze the function of marketing organizations as a process in dealing with customers, forming strong brands and market offerings, conveying or communicating values that can create long-term growth.

Marketing Management 1 course contributes to the graduate's competencies formulated in the Learning Outcomes of the Management Study Program Graduates. They are mastering the application of the concept of Marketing Management as a theoretical basis for analyzing various problems in organizations and society, applying management theories, analyzing management problems, developing alternative solutions to problems faced in the field of marketing, and evaluating and criticizing various current issues.

Teaching materials used so far are in the form of power points and textbooks. The main textbook is Marketing Management written by Phillip Kotler and Kevin Lane Keller Edition 15 E. Student-centered teaching methods are considered inadequate to be practiced at this time to achieve educational goals based on learning outcomes because the development of science and technology is very fast and massive and easy to access, changes in job competencies that take place very quickly require materials, media and learning processes that are flexible, fast and able to accommodate participatory democratization in the learning process. Therefore, the Government encourages universities to develop online learning in 
the form of e-learning in order to accommodate the current needs of students [1]

Currently, the assessment carried out in this course is by giving group assignments, quizzes, individual assignments, midterm, and final semester exams, and evaluations to students in the form of questionnaires to assess the effectiveness of the learning methods applied. Group assignments are given by means of the latest case analysis determined by the lecturer, and the lecturer adds the questions they will answer according to the chapter by chapter discussion in the main reference book.

So far, the teaching process of the Marketing Management 1 course uses more teaching methods by emphasizing understanding marketing management theory through the method of describing marketing concepts after that next week discussing cases to be determined by the lecturer. So that it causes students to feel bored because there is no animation media that attracts them to study this course material more deeply. As a result, students only understand the concept so that the styling of the concept of Marketing Management 1 is not optimal because of the low variation in both teaching methods and teaching media used.

Therefore, to improve student understanding in the Management study program of the Faculty of Economics, Andalas University for the Marketing Management 1 course, it is necessary to provide a learning method using the blended learning method. Andalas University already has a Learning Management System (LMS) platform, which is adequate for e-learning, but not many lecturers have made use of this LMS. Besides, it is stated in the academic regulation of Andalas University N0.1 of 2019, article 8, paragraph 8, that lectures can use blended-learning method. Therefore, these activities are designed to make intensive use of the LMS platform already owned by Universitas Andalas with the URL: https: //learn.unand.ac.id/.

All of researchers agree that blended learning is an integrated learning experience that is controlled and guided by the instructor whether in the form of face-to- face communication or his virtual presence. Technological innovation is expanding the range of possible solutions that can be brought on teaching and learning. Whether we are primarily interested in creating more effective learning experiences, increasing access and flexibility, reducing the cost of learning, it is likely that learning systems will provide a blend of face-to-face and computer mediated experiences [2]. This blended learning will create a learning experience for the learning outcomes determined in the Marketing Management 1.

Blended learning provides opportunities and challenges for today's education world. Blended learning, by interacting with almost every aspect of higher education, provides opportunities and challenges. This pedagogy alters many assumptions about the most effective way to support the educational environment. For instance, blending, like its counterpart active learning, is a personal and individual phenomenon experienced by students. Therefore, it should not be surprising that much of what we have called blended learning is, in reality,blended teaching that reflects pedagogical arrangements. Actually, the best we can do for assessing impact is to use measures such as success, grades, results of asesessment protocols, and student testimony about their learning experiences [3].

In adopting this blended learning, e-learning is used for five weeks/meetings in one semester, outside of the midterm and final exam. The lecturer has a semester learning plan in the form of blended learning, covering both synchronous and asynchronous learning activities. The teaching materials, such as video, audio, ppt, and texts, including the pdf version of the textbooks, are uploaded to the University Learning Management System or the i-learn platform.

The delivery of teaching materials has been carried out by optimizing Andalas University the I-learn facilities which include attendance, discussion forums, assignments, and videos. Student assignment assessments are formative assessment and summative assessment where the e-learning component includes the value of online lecture attendance, individual assignment scores, group assignment scores, and individual participation scores.

Based on the problems stated on the previous page, the e-learning method is a necessity because the Covid-19 pandemic requires lecturers to send teaching materials through cyberspace. Therefore, the application of I- learn is necessary. This study is, firstly, aimed to increase student comprehension of the Marketing Management 1 course by using the online learning method through the use of LMS. Second, it is to increase students' participation through delivery learning. Third, it is to build students' creativity through the provision of different attractive and fun learning materials, as well as a learning process that prioritizes the development of student creativity, capacity, and needs, as well as developing independence in seeking and finding knowledge.

\section{METHODS}

For the maximum output of this research, the objectives of the course and the achievement strategies used were designed by developing a Semester Learning Plan based on blended learning. It is executed using virtual asynchronous, which is independent and collaborative so that students living in areas with an unstable internet connection might access the materials on the I-learn platform owned by the Andalas University. All student assessments, such as assessment of learning outcomes, assessments on personal assignments, and assessors on group assignments, use the facilities provided on the I- learn platform. The 
curriculum used in the course is the Indonesian National Qualifications Curriculum (KKNI,) which has been compiled by the Management Study Program, Faculty of Economics, Andalas University, Padang.

Learning technology media used are facilities available on the I-learn platform. The teaching method adopted is the Blended-learning method which enables the lecturers to design learning content in the form of videos and optimize the learning delivery facilities that Andalas University already has, both synchronously and asynchronously. Andalas University I-learn facilities can be in the form of student attendance, discussion forums, and assignments. The use of I-learn is a mandatory learning platform and is a necessity for students during the Covid 19 pandemic as it is today. Because offline lecture meetings are a learning and teaching process activity that is prohibited by the Government, it is compulsory for study from home.

Making short videos on learning topics is the method of choice. Because it is quite applicable for students to follow when practicing the blended learning method. There are 4 videos made to support this blended learning.

Blended learning can improve the quality of learning. Blended learning is more than just enhancing lectures, it represents transformation in how we approach teaching and learning. The potential of blended leaning in higher education is promisingly tremendous, a further research into the relevant practices and their impact is essential. Follow up with blended learning is equally important to assess the effectiveness in terms of achieving learning outcomes, student satisfaction and overall learning experience.transforming the whole learning experience [4]

The implementation team for this course consists of 3 lecturers. Starting from the activity of making proposals, designing questionnaires, designing lecture materials in the form of videos, designing lecture materials in the form of assignments, making progress reports, making research reports and making articles and publishing articles.

\section{RESULTS AND DISCUSSION}

The implementation for the Semester Learning Plan with blended learning includes odd semester learning which contains an implementation plan that is applied to the odd semester of the 220/2021 Academic Year which refers to the Learning Outcomes of the Marketing Management 1 course. Marketing management course provides an understanding of managerial orientation, analytical approach, views from multi disciplines, its universal applications comprehensive and balanced coverage [5].
The evaluation of the implementation of blended learning is carried out at the end of the semester with the following parameters: a) the final score obtained by students, b) the level of individual participation in the online presentation process c) assessing student responses regarding the development of learning methods using blended learning. Evaluation is done by distributing questionnaires via google form. This form will be filled in by students at the 15 th meeting.

\section{CONCLUSION}

The implementation of learning with this online learning method has created student curiosity to find out what other videos the lecturer will share at the online learning meeting at the next meeting. It reveals that the students are much more excited about the learning and are more creative in exploring the technology used in the platform. This online learning method increases students' understanding of Marketing Management material for the better because the material provided is in the form of video.

\section{ACKNOWLEGMENT}

Our gratitude goes to the Institute for Educational Development and Quality Assurance (LP3M), University of Andalas for funding this activity through the Blended Learning Development and Implementation grant scheme (PPBL). Thank you is addressed to all students who were taking Marketing Management Class.

\section{REFERENCES}

[1] Institute for Development and Quality Assurance (LP3M) Andals University,. "Guidelines for the Formulation of Graduates' Soft Skills in the Curriculum and Integration in the Learning Process", Andalas University Press, Padang. 2016

[2] Bryan.A, Volchenkova, KN "Blended Learning: Definition, Models, Implications For Higher Education", Bulletin of the South Ural State University. Ser. Education. Educational Sciences. 2016, vol. 8, no. 2, pp. 24-30.DOI: $10.14529 /$ ped 160204

[3] Dziuban, C, Grahamz.C.R, Moskali .Patsy D ,Norberg.A, Sicilia.N, "Blended learning: the new normal and emerging technologies, 'International Journal of Educational Technology in Higher Education (2018) 15:3 DOI 10.1186/s41239-017-0087-5

[4] Jolly Sahni, "Does Blended Learning Enhance Student Engagement? Evidence from Higher Education ", Journal of e-Learning and Higher Education, Vol. 2019 2019, Article ID 121518, DOI: $10.5171 / 2019.121518$ 
[5] Kotler, Philip, Keller, Kevin Lane, Marketing

Manegement 15E. International Edition, New Jersey;Upper Saddle River.Person Education Inc, 2015 